printed, and of distributing a few others. It contains an account of experiments for the purpose of testing the action of sun and air on dried bacteria, which have some interest, but which the fear of trespassing unduly on your space prevents me from entering on here.

Melbourne, May 22

\section{Fireballs observed in the Netherlands}

IN the well-known "Meteoric Astronomy" of Dr. D. Kirkman, p. 67 , is to be found the following note, on the occasion of the interesting shower of dust and aërolites in Calabria on the I 3 th and 14th of March, I8I3. "The date of this remarkable occurrence is worthy of note, as a probable aërolite epoch. From the I 2 th to the 15 th of March we have the following falls of meteoric stones. . ." \& c. ( 7 cases).

In reference to this note it may interest your readers that on the night of 12-13 March last two great meteors were observed in two different places in the Netherlands. The first observation, made near the village of Haren (four and a half kilom. S. of Groningen), by the schoolmaster, Mr. H. Bos, at $\mathrm{I}$ a.m., refers to a bright fireball, shining with a splendid "bluish red" light, illuminating the night, leaving a violet train, which lasted some moments. The path seems to have been from a point not far beneath the zenith, in an azimuth of $115^{\circ}$ to another at $108^{\circ}$ azimuth, and had a length of $45^{\circ}$, which was traversed by the phenomenon in 4 or 5 seconds. After 85 seconds-measured afterwards by means of a watch and by the distance of the objects which the observer had passed, going with a known velocity-a full detonation, like a distant cannon-shot, was heard in the same direction.

On the same night, and at the same hour, another fireball was seen near the village of Bergen, in North Holland. The schoolmaster, J. Francken, gives me the following indications of its path, found by him after having interviewed the observer. It went from N.E. in altitude of $50^{\circ}$ to S.E. in an altitude of a little less than $40^{\circ}$ It is therefore impossible that this phenomenon should be the same as the former, the di:ection of the course being opposite. A second observer gave nearly the same direction.

It is worthy of remark that another violet meteor had been seen near Haren on March 12 at 8 p.m. in the S.W.

A fourth meteor of the greatest size, described as being as great as the full moon, was seen by three policemen, from whom I have received tolerably harmonising records, though they were standing in different positions in the town. The time of appearance was May $\mathbf{x}$, at 4 a.m. precisely, or perhaps three minutes afterwards, and the direction of the course was S.S.E. to N.N.E. It was described by one of the observers as beginning like a shooting star (though already lightening the sky), falling downwards and rising again in a curve from S.S.E. to N.N.E., increasing in the meanwhile to a great ball of a splendid purple light, and showing a train of a silvery colour. The phenomenon lasted 50 seconds (?) measured by a watch. No sound was heard. The disappearance was instantaneous. It is uncertain if an explosion was really observed. The altitude seems to have been at the beginning, and at the end point perhaps $10^{\circ}$, somewhat higher in the middle, as I have attempted to determine in loco. The second observer estimated the duration of the phenomenon to be 13 seconds. Even when this is accepted, the body must have been very distant, and of a great volume, though increased apparently by irradiation.

The same morning, at $3 \mathrm{~h} .45 \mathrm{~m}$. a.m. there was also seen a great meteor, going from W. to E. near Enumatil ( 8 kilom. W.), and at Assen (S. from Groningen). It seems not to be identical with the former. At Assen there was heard a buzzing sound. The Enumatil observers compare the phenomenon, whose colour was white with a red train, to a drum-major's staff. The Assen observers speak of a bluish train or tail, which seemed to be smoke. The same was seen by the sluice-keeper, G. Mulder, at Veenhuizen (W. of Assen), who heard also the buzzing sound, and gives also the direction, W.-E. The ball passed S. of the zenith (Assen).

Still another great fireball was observed at Bourtange (S.E. of Groningen) at $5 \mathrm{~h}$. $12 \mathrm{~m}$. (local time) a.m. on the same morning. It had a quick motion from S.W. to E. It gave the impression of being very near the earth, only some meters

I In the German journal, Sirius, edited by Dr. H. J. Klein, Bd. $\mathbf{x}$. (1882), p. 40, is mentioned likewise a fireball of the full moon size, from March $\mathrm{I}_{3}, \mathrm{I}_{75}$, by Mr. T. Köhl. above the houses. It seems to me uncertain whether it was a globulous lightning or a true fireball. The phenomenon showed a fiery tail and exploded without any sound.

Recapitulating, there seems to have been observed the following fireballs of great size :-

March I2, 8 p.m. (Groningen M. T.) at Haren.

\begin{tabular}{|c|c|c|c|c|}
\hline $\begin{array}{l}, \quad \text { I3, } \\
, \quad \text { I3, }\end{array}$ & a.m. & ,", & " & Bergen (N. Holland). \\
\hline ay $1,3.45$ & & ," & & Enumatil. \\
\hline , & , & ," & , & Probably \\
\hline & ," & 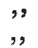 & $"$, & $\begin{array}{l}\text { Veenhuizen I } \\
\text { Groningen. }\end{array}$ \\
\hline
\end{tabular}

Finally a fireball or a globulous lightning.

May I, 345 a.m. (Groningen M.T.) at Bourtange.

Groningen, June 19

H. J. H. GRoneman

\section{Aluminium for Movable Coils}

AT the Oxford meeting of the Physical Society, after Dr. W. H. Stone's interesting description of an electrodynamometer designed for medical purposes with the movable coil, made of aluminium wire for the sake of lightness, I took the liberty to remark that about eight years ago Dr. Werner Siemens had made use of aluminium wire for the movable bobbin of his dynamo-relay.

I was then under the impression that this fact was probably not known in this country; a friend has, however, since called my attention to a short paragraph in the Telegraphic Fournal of 1878, p. 53 , in which it is already mentioned.

One of these dynamo-relays was shown working at the Paris Electrical Exhibition, and Messrs. Siemens and Halske have made use of the same principle in their so-called soot-recorder (see Telegraphic Fournal, 1878, p. 90), an instrument well suited for the registration of currents of varying direction and strength.

At the meeting I further said that in some of the coils made of very thin aluminium wire, I had found an increase of resistance after the lapse of some time, and that this increase was proved to exist at the place where two lengths of wire had been joined by twisting them round each other.

Some experiments were afterwards made to coat the ends of the wire with an electrolytic deposit of copper, and then solder them together; but the best and most natural way to overcome the difficulty is to make the coil all of one length of wire, and thereby dispense with all internal joints.

A similar increase of resistance at the place of contact between aluminium wire and mercury I had already observed several years previously; the cause of it seems to be the formation of a very thin film of aluminium oxide on the surface of the wire.

I have been led to make the above remarks after perusing the closing paragraph of Dr. Stone's article in NATURE, vol. Xxvi. p. 201 .

Woolwich, July 3

EUGENE OBACH

\section{The Recent Weather}

THE article published in NATURE, vol. xxv. p. 225, entitled "Recent Weather," attracted attention from meteorologists in China from the fact that the extraordinary character of the season therein discussed was observable in China also In my Report on the Health of Wenchau, I referred to the unprecedentedly high reading of the barometer in this part of the world, at the same time that a like phenomenon was observed in Western Europe.

NATURE records that November last showed the highest thermometrical range that has been known since thermometers came into use. On referring to the tables of Dr. Zrightsche (director of the Belgian Observatory at Peking), I find that the mean temperature at Shanghai of that month for a period of twelve years falls considerably below that of the record for November last; and finally we learn from NATURE that the winter of I88I-82 in Western Europe was an "open one," which was the case in Eastern Asia; the port of Tientsin, for example, having been closed by ice later, and opened to naviga. tion earlier than usual. When the meteorological reports are all gathered in, it will be found that the abnormalities which characterised last winter were coincident with like phenomena in this part of the world. $\quad$ D. J. MACGOWAN

Wenchau, May i7 